\title{
An Elaboration on the Effect of Reading Anxiety on Reading Achievement
}

\author{
Bijan Mohammadpur ${ }^{1,2} \&$ Narjes Ghafournia ${ }^{2}$ \\ ${ }^{1}$ Department of English, Khorasan Razavi Science and Research Branch, Islamic Azad University, Neyshabur, \\ Iran \\ ${ }^{2}$ Department of English, Neyshabur Branch, Islamic Azad University, Neyshabur, Iran \\ Correspondence: Narjes Ghafournia, Department of English, Neyshabur Branch, Islamic Azad University, \\ Neyshabur, Iran. Tel: 98-915-313-0060. E-mail: narjesghafournia@yahoo.com
}

Received: March 4, 2015 Accepted: April 22, 2015 Online Published: June 29, 2015

doi:10.5539/elt.v8n7p206 URL: http://dx.doi.org/10.5539/elt.v8n7p206

\begin{abstract}
The presentstudy was an elaboration on the effect of foreign language anxiety on reading comprehension achievement of Iranian EFL learners. The participants comprised 100 BA students, doing General English Course in different academic fields at Islamic University of Neyshabur. The participants took a reading proficiency test of TOEFL and answered a likert scale reading anxiety questionnaire, derived from Sarson's (1975) anxiety scale. The collected data were subjected to a set of parametric statistical analyses, including descriptive and inferential statistics such as one-way analysis of variance and post hoc tests. The findings presented significant differences among the participants at different reading ability levels. The students at the high and intermediate reading levelsdiffered significantly from the students at the low reading level in reading anxiety. To put it simply, there is a negative relationship between the students' reading level and reading anxiety. The findings are of significance for language teachers as well as curriculum planners to reduce the affective filters and debilitating factors in language-learning environment to improve language learners' reading ability. One important way to reduce reading anxiety is to expose language learners to comprehensible reading sources and culturally familiar texts, which develop learners' feeling of reassurance and self-confidence.
\end{abstract}

Keywords: reading comprehension anxiety, foreign language anxiety, test anxiety

\section{Introduction}

In the teaching and learning of English as a second or foreign language, the effective achievement of four language skills of reading, writing, listening, and speaking areconsidered important. However, reading is by far one of the most important skills for many L2 language learners, particularly for university students in EFL settings. To put it simply, success of learning at university level depends upon the students' ability to read written language with a relatively good comprehension (Dechant \& Smith, 1977; Grabe \& Stoller, 2001; Shapiro, 2004).

Some people are successful in second or foreign language learning while others struggle with different aspects of language learning. Where do these individual differences come from? What is the role of individual differences in second language learning? These issues have been debated in the field of second/foreign language learning for a long time by many researchers (e.g., Bailey, 1999; Chastain, 1975; Kleinmann, 1977; Tucker et al., 1976).

Earlier studies on second language learning have attributed individual differences in language learning to cognitive factors such as language aptitude and intelligence. However, given that human beings are emotional creatures, it is evident that human behaviors are considerably influenced by affective variables. From this perspective, foreign language educators have been concerned with significant role of affective variables in second language learning (Gokulnathan, 1971; Hundal \& Singh, 1971; Liu \& Jackson, 2008; Onwuegbuzie \& Jiao, 2002). Among different affective variables, anxiety poses major problems in the cognitive process of learning (Ahmad \& Zafar, 2010; Horwitz \& Young, 1991; Sellers, 2000; Sharma \& Gandhi, 1971).

Earlier studies on the effects of anxiety on second language learning revealed inconsistent andconfusing results (e.g., Kleinmann, 1977; Liu \& Jackson, 2008; Sparks \& Ganschow, 1991; Tucker et al., 1976). The problem as E. Horwitz, M. Horwitz, and Cope (1986) asserted might be related to this fact that "second language research has neither adequately defined foreign language anxiety nor described its specific effects on foreign language 
learning" (p. 125). More importantly, it is possible that researchers are not measuring what they assume to measure (Bachman, 1990; Bachman \& Palmer, 2010).

Horwitz et al. (1986) identified foreign language anxiety as "a distinct complex of self-perceptions, beliefs, feelings, and behaviors related to classroom language learning arising from the uniqueness of language-learning process" (p. 128). They found that foreign language anxiety is a distinct and complex phenomenon that might arise from the mismatch between foreign language students' mature thoughts and their immature foreign language proficiency. At this point, researchers began to adapt a systematic approach to foreign language anxiety through employing specific anxiety measurement instruments such as Foreign Language Classroom Anxiety Scale (FLCAS), developed byHorwitz et al. (1986).

Many earlier researchers reported a consistent negative relationship between language anxiety and L2 learning (e.g., Aida, 1994; Burgucu et al., 2010; DeDeyn, 2011; Djigunovic, 2006; Dordi Nejad et al., 2012; Elkhafaifi, 2005; Horwitz, 2001; MacIntyre \& Gardner, 1991a; Matsuda \& Goble, 2004; Saito \& Samimy, 1996; Young, 1991). As anxiety is a major threat to an individual's self-concept, it can pose major problems for L2 learners' speaking ability (Horwitz et al., 1986). Thus, speaking is considered the most anxiety-provoking task among the other skills.

Although reading comprehension is the major focus of most foreign language-teaching programs, the relationship between L2 reading and anxiety has been investigated less extensively (Dewaele et al., 2008; Horwitz, 2009; Matsuda, 2004; Sellers, 2000). It might seem at first glance that foreign language reading is less influenced by foreign language anxiety, yet many learners do experience reading-related anxiety, which can lead to poor reading comprehension (Saitoet al., 1998). Anxiety arousal has been identified to be related to self-related thoughts and worries. Anxiety takes up processing capacity and diminishes the amount of attention that should be dedicated to the completion of a certain task (Eysenck \& Calvo, 1992). Given that human beings are limited in their attention and capacity, self-related cognition plays a negative role such as a distracter or hindrance during cognitive reading processing. As a result, poor reading performance of anxious learners may depend largely to reading anxiety. On the other hand, non-anxious learners may be less bothered by task-irrelevant thought; therefore, they may have more attention and capacity contributing to the process of reading comprehension.

In view of this, the purpose of this study is to investigate the effects of foreign language anxiety on Iranian EEL learners' reading comprehension test-taking processing. Foreign language anxiety certainly affects a reader's reading processing in several ways including readers' cognitive interference and strategy use, which in turn affect reading comprehension process. Anxiety affects curiosity of students, which reduces the functioning of cognitive abilities and capacities such as logical thinking, keen observation, and questioning disturbing reading comprehension process.

Most of earlier studies have explored the effect of test anxiety on reading comprehension at beginning levels with young students (e.g., Chan \& Wu, 2000, 2004). As English reading comprehension is the core of attention in English-teaching curriculums at the universities in Iran, the necessity of exploring the effect of test anxiety on reading achievement at university level is greatly felt. The results can definitely improve the efficacy of teaching programs and can provide useful insights into the effective ways language teachers can reduce affective filters, particularly test anxiety in their students, which can increase their motivation and positive attitudes towards learning English even outside the university programs. In his conceptual framework of language use, Bachman (1990) introduced some systematic and unsystematic factors, affecting test performance. Test anxiety is among systematic factors, affecting test performance and language use, which can be controlled systematically. His framework can act as a strong conceptual framework for the present study. To this end, the present study directed its attention to Iranian EFL learners' reading anxiety and its effects on their reading achievement, assessed in terms of their level of reading proficiency at the end of instructional reading programs at university.

The findings of the present study are of significance as they provide language instructors at universities with useful information to decrease language learners' reading anxiety as one of the most debilitating factors in reading achievement. There exist many students with enough linguistic knowledge, but due to great anxiety over accomplishing English reading comprehension tasks, they are not able to use their full potentialities. If language instructors are equipped with required information to assist language learners in coping with their distress, they cannot only improve efficacy of language-teaching programs, but also can save their time and energy. Besides, the findings can encourage language teachers to pay serious attention to psychological dimension of language learning, which is often taken for granted despite its vital impact on learning process.

\section{Relevant Review of Literature}

There are different factors influencing test takers' performance, including personality types, intelligence, 
motivation, attitude, age, gender, and anxiety (Skehan, 1989). Languageacquisition can be achieved naturally or innately; however, learning a foreign language in theclassroomis full of challenges for most of language learners. Hence, L2 test- taking process is full of obstacles and challenges to cope. One of the known big challenges is concerned with L2 learners' affective factor or test anxiety (Wu \& Menon, 2010). Anxiety plays an important role in language learning (Horwitz et al., 1986). Language learning anxiety is "a distinctcomplex of self-perceptions, beliefs, feelings, and behaviors related to classroom languagelearning arising from the uniqueness of language learning process" (Horwitz et al., 1986, p. 128).

The problemof test anxiety occurs when intrusive thoughts interfere with task-focusedthinking (Sarason, 1984, p. 929). On the other hand, anxiety is usually defined as "a complex state that includes cognitive, emotional, behavioral, and bodily reactions" (Sarason, 1984, p. 931). Almost everyone experiences feeling of anxiety at some point in his/her life, which affects the performance. Some people feel more anxious than others. The feeling of anxiety may positively motivate some people to perform more effectively whereas the same feeling may negatively prohibit others' performances by disrupting mental processes. Test anxiety, as Bachman (1990) asserted, is a variable related to test-takers' characteristics. It is of vital importance because of the most frequent useof tests and their importance to students. Test anxiety may have different degrees depending on various factors such as language learners, language ability, language-learning attitude, language-learning aptitude, intelligence, emotional intelligence, gender, age, and so forth. In addition, it relies upon the test takers' perception of test difficultyin test-taking time. Kahan (2008) showed that students with high and lowlevels of test anxiety have lower academic performance than the students with moderate level of testanxiety. A moderate level of anxiety is helpful in keeping people hardworking and responsiblefor what they have to do. Brantmeier (2005) asserted that anxiety about reading at advanced levels may not be a functionof reading itself, but rather it can be a function of oral or written reading comprehension tasks.

Concerning the mentioned points, the present study aimed at investigating the impact of test anxiety on reading comprehension achievement of Iranian EFL learners. The following research question wasexamined in this study.

Research Question:

What is the effect of foreign language reading anxiety on reading comprehension achievement of Iranian EFL learners?

\section{Methodology}

\subsection{Overview}

This section presents the description of the participants, measurement instruments, data collection procedure, and data analysis.

\subsection{Participants}

The participants of this study were the students doing general English course with its focus on reading comprehension. The participants were females and males in different academic disciplines. Purposive sampling was done to gather required data to accomplish the purpose of the study.

\subsection{Instrumentation}

\subsubsection{A Reading Test}

To measure reading ability of the participants, they took a reading comprehension test, derived from Barron's (2010) TOEFL preparation test. The reading test included 50 reading test items in multiple-choice format. The reliability index of the test items was calculated using KR-21 formula. The reliability index was $\alpha=0.86$, which is high and acceptable. The time for administrating the test was 55 minutes.

\subsubsection{A Reading Anxiety Questionnaire}

To measure the participants' reading test anxiety, the Reading Test Anxiety scale was completed by all the students after taking the reading test. The Reading Test Anxiety scale (Sarason, 1975) is a 25-item measure, focusing only on reading test anxiety, formerly referred to as worry (Liebert \& Morris, 1967). The questionnaire was translated into Persian, the participants' mother tongue, and was piloted on a sample of 30 students before the actual administration. The reliability index was calculated through using Cronbach's alpha coefficient. The reliability index was 0.72 , which is acceptable.

\subsection{Procedure}

To accomplish the purpose of the study, the participants took a reading comprehension part of a standardized preparation TOEFL test (Barron, 2010). Based on their scores, they were divided into three groups of reading 
proficiency, high, intermediate, and low. They also completed a reading test anxiety questionnaire and identify their degree of stress and tension before, during, and after test taking session. Then, the gathered data were reviewed and checked by the researcher, and invalid data were deleted. Finally, the acceptable valid data were subjected to a set of parametric statistical procedures.

\section{Results and Discussion}

The present study was designed to explore Iranian EFL students' reading anxiety and its effects on reading processing and comprehension. This sectionpresents the results of the statistical analyses of the data using SPSS version 19.

First, descriptive statistics, including minimum, maximum, mean, standard deviation, skewness, and kurtosis were calculated for the participants' reading comprehension anxiety. The results can be seen in Table 1 . To check the normal distribution of the data, skewness and kurtosis values were also checked.

Table 1. Descriptive statistics for reading comprehension anxiety

\begin{tabular}{|c|c|c|c|c|c|c|c|c|c|}
\hline & $\mathrm{N}$ & Min. & Max. & Mean & $\begin{array}{l}\text { Std. } \\
\text { Deviation }\end{array}$ & Skewnes & & Kurtosis & \\
\hline & Statistic & Statistic & Statistic & Statistic & Statistic & Statistic & Std. Error & Statistic & Std. Error \\
\hline $\begin{array}{l}\text { Reading } \\
\text { Ability }\end{array}$ & 100 & 0 & 5 & 3.01 & 1.283 & -.341 & .241 & -.584 & .478 \\
\hline $\begin{array}{l}\text { Reading } \\
\text { Anxiety }\end{array}$ & 100 & 21.00 & 48.00 & 35.5900 & 5.97823 & -.560 & .241 & -.102 & .478 \\
\hline $\begin{array}{l}\text { Valid N } \\
\text { (listwise) }\end{array}$ & 100 & & & & & & & & \\
\hline
\end{tabular}

As Table 1 shows, skewness and kurtosis values are within the range of -2 and +2 . Therefore, it can be said that the variables enjoy normal distribution. Moreover, the normal curve distribution was used to see the normality of the data graphically.

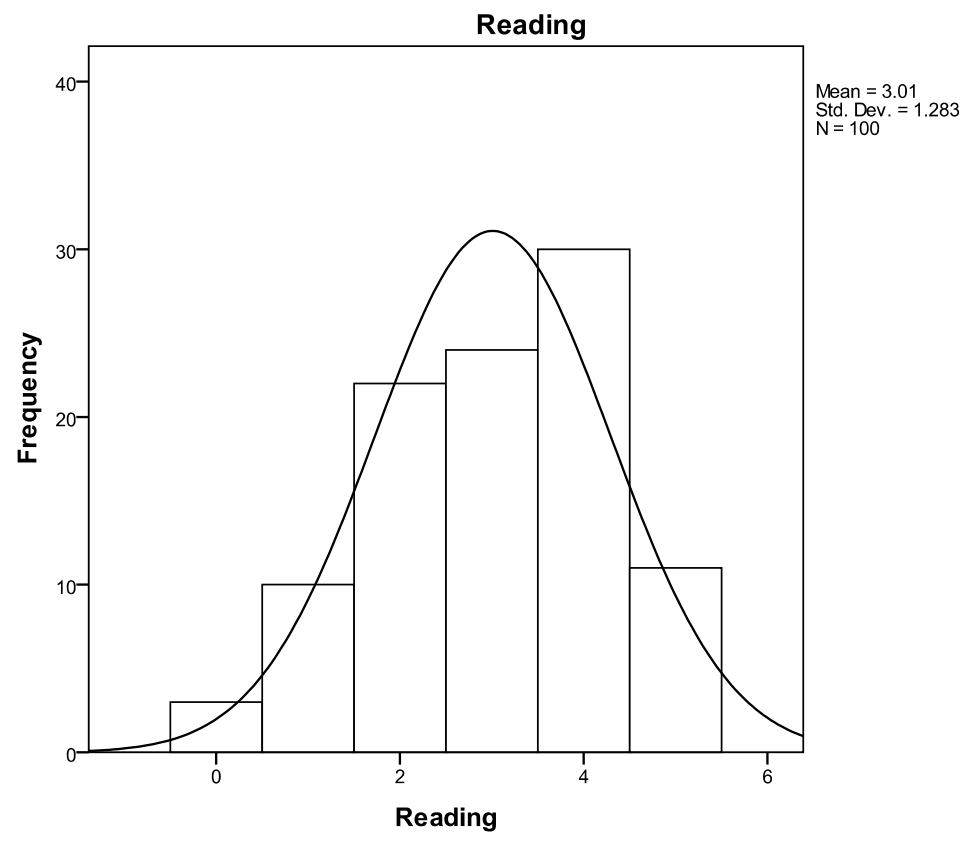

Figure 1. Normal distribution for the participants' reading ability 


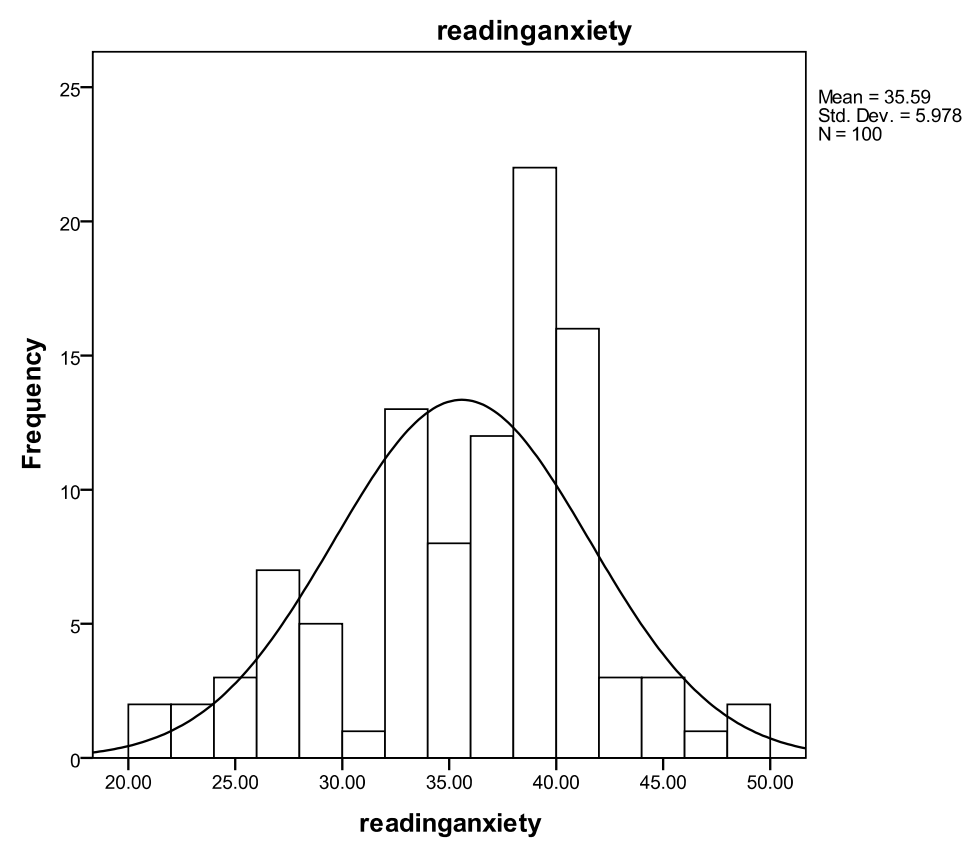

Figure 2. Normal distribution for the participants' reading anxiety

Then, the reliability indexes of the reading comprehension test anxiety questionnaire as well as reading scores were checked. Cronbach's alpha was used to check the internal consistency of the questionnaire items as well as reading scores. The results can be seen in Table 2 .

Table 2. The reliability index of the questionnaire

\begin{tabular}{ll}
\hline Variable & Cronbach's alpha \\
\hline Reading anxiety & .72 \\
Reading score & .81 \\
\hline
\end{tabular}

As Table 2 shows, Cronbach's alpha is .72 for reading anxiety questionnaire items and .81 for the reading comprehension achievement or reading scores. As both of them are above the recommended value of .70, they are reliable scales.

In order to answer the research question, posed in this study, Iranian EFL learners were divided into three groups of low, intermediate, and high based on their performances in the reading comprehension test. Then, the three groups were compared with regard to their reading anxiety. The purpose was to see whether three groups with different levels of reading comprehension had different levels of reading anxiety. Descriptive statistics for three groups can be seen in Table 3 and in Figure 2.

Table 3. Descriptive statistics for reading comprehension anxiety

\begin{tabular}{|c|c|c|c|c|c|c|c|c|}
\hline & \multirow{2}{*}{$\mathrm{N}$} & \multirow{2}{*}{ Mean } & \multirow{2}{*}{ Std. Deviation } & \multirow{2}{*}{ Std. Error } & \multicolumn{2}{|c|}{$95 \%$ Confidence Interval for Mean } & \multirow{2}{*}{ Min } & \multirow{2}{*}{ Max } \\
\hline & & & & & Lower Bound & Upper Bound & & \\
\hline Low & 13 & 40.6923 & 6.06059 & 1.68091 & 37.0299 & 44.3547 & 29.00 & 48.00 \\
\hline Mid & 46 & 36.7391 & 4.85997 & .71656 & 35.2959 & 38.1824 & 26.00 & 44.00 \\
\hline High & 41 & 32.6829 & 5.67644 & .88651 & 30.8912 & 34.4746 & 21.00 & 39.00 \\
\hline Total & 100 & 35.5900 & 5.97823 & .59782 & 34.4038 & 36.7762 & 21.00 & 48.00 \\
\hline
\end{tabular}


As shown in Table 3, the mean score of reading anxiety was the lowest for the high proficient $(\mathrm{M}=32.6829)$ learners whereas the mean score was the highest $(\mathrm{M}=40.6923)$ for the low proficient learners. The students at the low proficiency group got the highest maximum score $(\mathrm{Max}=48)$ while the students at the high proficiency group got the lowest maximum score $(\operatorname{Max}=39)$. The mean score of the student in the middle group was in between $(\mathrm{M}=36.7391)$. The mean score of the total students, regardless of their proficiency level, was $(\mathrm{M}=$ 35.5900). The graphic representation of the relationship between reading anxiety and reading achievement is shown in Figure 3.

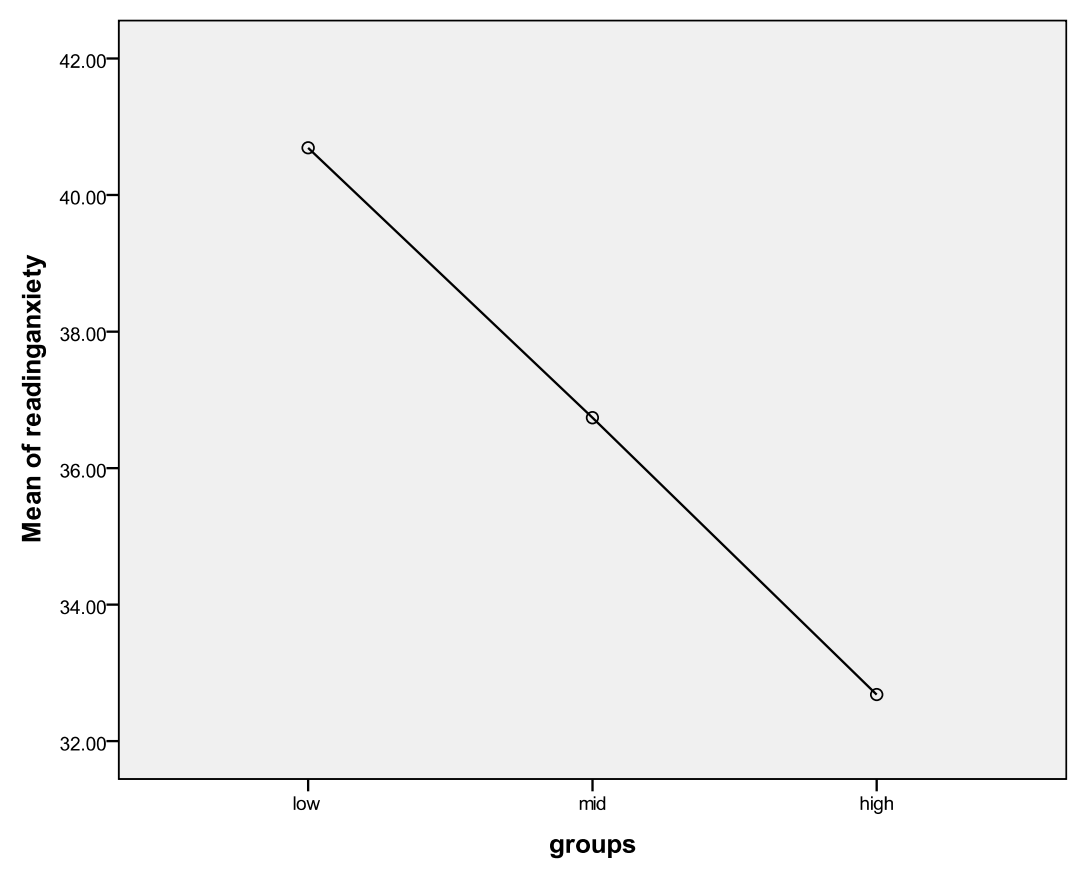

Figure 3. Relationship between the participants' reading anxiety and reading achievement

As shown in the figure, there is a negative relationship between reading achievement and the participants' reading anxiety. As depicted in Table 3 and Figure 3, the mean of reading anxiety for the low group is 40.69, for the middle group is 36.73 , and for the high group is 32.68 . To see whether these differences are statistically significant, a one-way ANOVA was run. The result can be seen in Table 4.

Table 4. Analysis of variance for reading anxiety and reading achievement

\begin{tabular}{llllll}
\hline & Sum of Squares & df & Mean Square & F & Sig. \\
\hline Between Groups & 745.673 & 2 & 372.837 & 12.951 & .000 \\
Within Groups & 2792.517 & 97 & 28.789 & & \\
Total & 3538.190 & 99 & & & \\
\hline
\end{tabular}

As Table 4 indicates, there is a statistically significant difference among three groups with regard to reading anxiety $[\mathrm{F}(97,2)=12.95, \mathrm{p}<.05]$. To locate the exact place of difference, post-hoc analysis was run. The results can be seen in Table 5 . 
Table 5. Multiple comparisons among the means

\begin{tabular}{|c|c|c|c|c|c|c|}
\hline \multirow{2}{*}{ (I) Groups } & \multirow{2}{*}{ (J) Groups } & \multirow{2}{*}{$\begin{array}{l}\text { Mean } \\
\text { Difference (I-J) }\end{array}$} & \multirow{2}{*}{ Std. Error } & \multirow{2}{*}{ Sig. } & \multicolumn{2}{|c|}{ 95\% Confidence Interval } \\
\hline & & & & & Lower Bound & Upper Bound \\
\hline \multirow{2}{*}{ Low } & Mid & $3.95318^{*}$ & 1.68534 & .044 & -.0583 & 7.9647 \\
\hline & High & $8.00938^{*}$ & 1.70783 & .000 & 3.9444 & 12.0744 \\
\hline \multirow{2}{*}{ Mid } & Low & $-3.95318^{*}$ & 1.68534 & .044 & -7.9647 & .0583 \\
\hline & High & $4.05620^{*}$ & 1.15239 & .002 & 1.3133 & 6.7992 \\
\hline \multirow{2}{*}{ High } & Low & $-8.00938^{*}$ & 1.70783 & .000 & -12.0744 & -3.9444 \\
\hline & Mid & $-4.05620^{*}$ & 1.15239 & .002 & -6.7992 & -1.3133 \\
\hline
\end{tabular}

*. The mean difference is significant at the 0.05 level.

As Table 5 indicates, there is a statistically significant difference between the low and middle groups (mean difference $=3.95, \mathrm{p}<.05$ ), low and high groups (mean difference $=8.00, \mathrm{p}<.05$ ), and middle and high groups (mean difference $=4.05, \mathrm{p}<.05$ ). As the mean of the low group is higher than that of the middle and high group, and also the mean of the middle group is higher than that of the high group with regard to reading anxiety, it can be concluded that the Iranian EFL learners, who have a better performance in reading comprehension, have lower levels of reading anxiety. In other words, when learners' reading comprehension anxiety increases, theirreading performance or reading achievement decreases.

Hence, the findings are in accord with the earlier findings (e.g., Argaman \& Abu-Rabia, 2002; Cassady, 2004; Kondo, 1997; MacIntyre, 1995; Moutafi et al., 2006; Nelson \& Hembree, 2011; Saito et al., 1999; Sarason \& Sarason, 1990; Young , 2000) in that there is a negative relationship between the participants' reading ability and reading test anxiety. To put it simply, the more proficient language learners are, the less anxious they are in comprehending reading texts and answering reading comprehension questions.

\section{Conclusion and Pedagogical Implications}

The aim of the present study was to investigate Iranian EFL students' reading anxiety. In addition to obtaining a descriptive explanation of students' affective feelings when reading in a foreign language, the study attempted to address specific research question concerned with the relationship between the participants' reading anxiety and reading ability or achievement, measured through a particular reading comprehension test. The findings manifested a direct negative relationship between the participants' reading ability and reading anxiety. In other words, the more stressful the readers are, the less skillful they are in taking reading tests. High proficient learners feel less stress; therefore, they accomplish reading tasks more successfully than low proficient learners, who often experience stressful feelings while test taking.

The findings give rise to some pedagogical implications for reading instruction. Even though reading seems at first glance the least anxiety-provoking part of the curriculum, the findings call for the recognition of foreign language reading anxiety and its effects on reading performance. Similar to Horwitz's et al. (1986) suggestions, there are several approaches that foreign language educators can do to help reduce anxiety. Above all, language teachers can help students deal with reading-related anxiety by preparing the students for the possibility of reading difficulties and anxiety. Foreign language students might be aware of the debilitating effects of anxiety on their speaking within a communication context, but they might not expect that foreign language reading is also anxiety-provoking. Knowing the fact that reading is anxiety-provoking, language teachers can raise awareness about the existence of anxiety in foreign language reading and let students know that they are not alone when struggling with reading-related anxiety. Language teachers can provide learners with enough reassurance and can help them overcome probable anxiety reactions (Sellers, 2000).

In addition, rhetorical organization and cultural topics are possible sources of foreign language reading anxiety. Language teachers can incorporate instructional practices in particular ways to raise awareness about these differences. As anxious students feel intimidated by English texts, filled with English letters, language learners should be gradually exposed to English texts with high readability level. Rhetorical organization also contributes to reading anxiety (Lee, 1999). Anxious learners might feel frustrated when they overcome different orthography, but still cannot comprehend the text because the way new information is developed may be different from what they expect. Language teachers can exploit the discourse or rhetorical aspects of a text in a way that helps readers get used to the difference and understand the text more effectively. 
Additionally, teachers should pay attention to the selection of texts especially when using culturally authentic texts. Language learners certainly feel difficulty when reading texts containing culturallyunfamiliar topics. Teachers should provide language learners with a variety of familiar cultural texts within an appropriate level of difficulty known as comprehensible input. It is also helpful to talk about cultural topics of the texts before assigning students reading tasks. This finding lends support to the view that if comprehensive reading instruction is offered, students can gain confidence in foreign language reading (Lehr \& Osborn, 2005).

Another way to facilitate reading comprehension process is to make learning context less stressful. Because a low-stress language learning environment is believed to facilitate acquisition of the foreign language by allowing students to concentrate fully on reading rather than being distracted by self-deprecating worry and fear of evaluation (Krashen, 1982). Thus, language teachers can help students reduce cognitive interference by creating warm and embracing atmosphere.

The results of this study suggest that anxious students' reading processing is negatively interfered with task-irrelevant thoughts such as fear of negative evaluation or self-worries. Language teachers should give students enough time to comprehend the text and compensate for lack of mental capacity with increased time and effort. As the findings demonstrated, students would feel frustrated and anxious when they realized they have insufficient time to comprehend the text. Although timed-reading is a necessary instruction for advanced students to be a fluent reader, an exclusive focus on timed-reading activity should not be encouraged for anxious learners until they can deal with reading related anxiety(Huang et al., 2009).

\section{References}

Ahmad Khan, Z., \& Zafar, S. (2010). The effects of anxiety on cognitive processing in English language learning. English Language Teaching, 3(2), 200-209.

Aida, Y. (1994). Examination of Horwitz, Horwitz, and Cope's construct of foreign language anxiety: The case of students of Japanese. The Modern Language Journal, 78(2), 155-168.

Argaman, O., \& Abu-Rabia, S. (2002). The influence of language anxiety on English reading and writing tasks among native Hebrew speakers. Language, Culture and Curriculum, 15(2), 143-160. http://dx.doi.org/10.1080/07908310208666640

Bachman, L. F. (1990). Fundamental considerations in language testing. Oxford University Press Oxford.

Bachman, L. F., \& Palmer, A. S. (1996). Language testing in practice: Designing and developing useful language tests. Oxford: Oxford University Press.

Bailey, K. M. (1999). Washback in Language Testing (TOEFL Monograph Series, MS 15). Princeton, NJ: Educational Testing Service.

Brantmeier, C. (2005). Anxiety about L2 reading or L2 reading tasks? A study with advanced language learners. The Reading Matrix, 5(2), 67-85.

Burgucu, A., Han, T., Engin, A. O., \& Kaya, M. D. (2010). Who are Our Students? Investigating Learners' Risk Taking Ability and Achievement on Second Language Acquisition. In 2nd International Symposium on Sustainable Development, June 8-9 2010, Sarajevo. Retrieved from http://eprints.ibu.edu.ba/320/1/ISSD2010Socialscience_p1-p6.pdf

Cassady, J. C. (2004). The impact of cognitivetest anxiety across the learning-testing cycle. Learning and Instruction, 14(6), 569-592. http://dx.doi.org/10.1002/acp.968

Chan, D. Y. C., \& Wu, G. C. (2000). A study of foreign language anxiety of elementary school EFLlearners in Taiwan. Paper presented at the 2000 Educational Academic Conference, 85-100.

Chan, D. Y. C., \& Wu, G. C. (2004). A Study of foreign language anxiety of EFL elementary schoolstudents in Taipei County. Journal of National Taipei Teachers College, 17(2), 287-320.

Chastain, K. (1988). Developing second language skills: Theory and practice (3rd ed.). San Diego, CA: Harcourt Brace Jovanovich.

Dechant, E., \& Smith, H. (1977). Psychology in teaching and reading. New Jersey: Prentice-Hall, Inc.

DeDeyn, R. (2011). Student identity, writing anxiety, and writing performance: A correlational study (Master's thesis). Available from ProQuest Dissertations and Theses database.

Dewaele, J.-M., Petrides, K. V., \& Furnham, A. (2008). Effects of trait emotional intelligence and sociobiographical variables on communicative anxiety and foreign language anxiety among adult 
multilinguals: A review and empirical investigation. Language Learning, 58(4), 911-960. http://dx.doi.org/10.1111/j.1467-9922.2008.00482.x

Djigunovic, J. M. (2006). Language anxiety and language processing. EUROSLA Yearbook, 6, 191-212. http://dx.doi.org/10.1075/eurosla.6.12mih

DordiNejad, F. G., Hakimi, H., Ashouri, M., Dehghani, M., Zeinali, Z., Sadegh-Daghighi, M., \& Bahrami, N. (2011). On the relationship between test anxiety and academic performance. Procedia Social and Behavioral Sciences, 15, 3774-3778.

Elkhafaifi, H. (2005). Listening comprehension and anxiety in the Arabic language classroom. Modern Language Journal, 89(2), 206-220. http://dx.doi.org/10.1111/j.1540-4781.2005.00275.x

Eysenck, M. W., \& Calvo, M. G. (1992). Anxiety and performance: The processing efficiency theory. Cognition and Emotion, 6, 409-434. http://dx.doi.org/10.1080/02699939208409696

Gokulnathan, P. P. (1971). A Study of Achievement related Motivation (n. Achievement and Anxiety) and Educational Achievement among Higher Secondary Pupis (Doctoral Dissertation). Dibrugarh University.

Grabe, W., \& Stoller, F. L. (2001). Reading for academic purposes: Guidelines for the ESL/EFL teachers. In M. Celce-Murcia (Ed.), TeachingEnglish as a second or foreign language (pp. 187-203). US: Heinle \& Heinle.

Horwitz, E. K. (2001). Language anxiety and achievement. Annual Review of Applied Linguistics, 21, 112-126.

Horwitz, E. K., \& Young, D. J. (Eds.). (1991). Language anxiety: From theory and research to classroom implications. Upper Saddle River, NJ: Prentice Hall.

Horwitz, E. K., Horwitz, M. B., \& Cope, J. A. (1986). Foreign language classroom anxiety. The Modern Language Journal, 70(2), 125-132. http://dx.doi.org/10.2307/327317

Horwitz, E. K., Tallon, M., \& Luo, H. (2009). Foreign language anxiety. In J. C. Cassady (Ed.), Anxiety in schools: The causes, consequences, and solutions for academic anxieties. New York: Peter Lang.

Huang, H.-C., Chern, C.-L., \& Lin, C.-C. (2009). EFL learners' use of online reading strategies and comprehension of texts: An exploratory study. Computers \& Education, 52(1), 13-26. http://dx.doi.org/10.1016/j.compedu.2008.06.003

Hundal, P. S., \& Singh, M. (1971). A Factory Analytical Study of Intellectual and Non intellectual Characteristics. Multivariate Behaviour Research, 6, 505-514. http://dx.doi.org/10.1207/s15327906mbr 0604_9

Kleinmann, H. H. (1977). Avoidance behaviour in adult second language acquisition. Language Learning, 27, 93-107. http://dx.doi.org/10.1111/j.1467-1770.1977.tb00294.x

Kondo, D. S. (1997). Strategies for coping with test anxiety. Anxiety, Stress and Coping, 10, 203-215. http://dx.doi.org/10.1080/10615809708249301

Krashen, S. D. (1982). Principles and practice in second language acquisition. New York: Pergamon Press.

Lee, J. F. (1999). Clashes in L2 reading: Research versus practice and readers' misconceptions. In D. J. Young (Ed.), Affect in foreign language and second language learning: A practical guide to creating a low-anxiety classroom atmosphere (pp. 49-63). New York: McGraw-Hill.

Lehr, F., \& Osborn, J. (2005). A focus on comprehension. Pacific Resources for Education and Learning.

Liu, M., \& Jackson, J. (2008). An exploration of Chinese EFL learners' unwillingness to communicate and foreign language anxiety. The Modern Language Journal, 92(1), 71-86. http://dx.doi.org/10.1111/j.1540-4781.2008.00687.x

MacIntyre, P. D. (1995). How does anxiety affect second language learning? A reply to Sparks and Ganschow. The Modern Language Journal, 79(1), 90-99. http://dx.doi.org/10.1111/j.1540-4781.1995.tb05418.x

MacIntyre, P. O., \& Gardner, R. C. (1994). The Subtle Effects of Language Anxiety on Cognitive Processing in the Second Language. Language Learning, 44, 283-305.

Matsuda, S., \& Gobel, P. (2004). Anxiety and predictors of performance in the foreign language classroom. System, 32(1), 21-36. http://dx.doi.org/10.1016/j.system.2003.08.002

Onwuegbuzie, A., \& Jiao, Q. G. (2002). Library anxiety and the educational use of the internet. University of Florida: Tampa. 
Saito, Y., \& Samimy, K. K. (1996). Foreign language anxiety and language performance: A study of learner anxiety in beginning, intermediate, and advanced-level college students of Japanese. Foreign Language Annals, 29(2), 239-252. http://dx.doi.org/10.1111/j.1944-9720.1996.tb02330.x

Saito, Y., Horwitz, E. K., \& Garza, T. J. (1999). Foreign language reading anxiety. Modern Language Journal, 83(2), 202-218.

Saito, Y., Thomas, G. J., \& Horwitz, E. K. (1998). Foreign Language Reading Anxiety. The Modern Language Journal, 83(2), 202-218. http://dx.doi.org/10.1111/0026-7902.00016

Sarason, I. G. (1975). Test anxiety, attention and the general problem of anxiety. In C. D. Spielberger, \& I. G. Sarason (Eds.), Stress and anxiety (Vol. 1, pp. 165-187). New York: Hemisphere Publishing Corporation.

Sarason, I. G. (1984). Stress, anxiety, and cognitive interference: Reactions to tests. Journal of personality and social psychology, 46(4), 929-938. http://dx.doi.org/10.1037/0022-3514.46.4.929

Sellars, V. (2000). Anxiety and reading comprehension in Spanish as a foreign language. Foreign Language Annals, 33(5), 512-521. http://dx.doi.org/10.1111/j.1944-9720.2000.tb01995.x

Shapiro, E. S. (2004). Academic skills problems: Direct assessment and intervention (3nd ed.). New York: Guilford Press.

Sharma, K. L., \& Gandhi, N. (1971). Hierarchy and among of Fear in Low and High Anxious groups of Students. Indian Psychological Review, 8, 29-30.

Skehan, P. (1989). Individual differences in second-language learning. London: Edward Arnold.

Sparks, R. J., \& Ganschow, L. (1991). Foreign language learning differences: Affective or native language aptitude? The Modern Language Journal, 17(1), 2-16.

Tucker, G. R., Hamayan, \& Genesee. (1976). Affective, cognitive and social factors in second language acquisition. Canadian Modern Language Review, 32, 214-226.

Wu, S., \& Menon, V. (2012). Scale for Early Mathematics Anxiety (SEMA) in Young Children. Retrieved from http://www.scsnl.stanford.edu

Young, D. (2000). An investigation into the relationship between L2 reading anxiety and L2 reading comprehension, and self-reported level of comprehension, topic familiarity, features of an L2 text and reading ability in the L1 and L2. In R. Leow, \& C. Sanz (Eds.), Current Research on the Acquisition of Spanish (pp. 15-33). Somerville: Cascadilla Press.

Young, D. J. (1991). Creating a low-anxiety classroom environment: What does language anxiety research suggest? The Modern Language Journal, 75, 426-437. http://dx.doi.org/10.1111/j.1540-4781.1991.tb05378.x

\section{Copyrights}

Copyright for this article is retained by the author(s), with first publication rights granted to the journal.

This is an open-access article distributed under the terms and conditions of the Creative Commons Attribution license (http://creativecommons.org/licenses/by/3.0/). 